\title{
Apparent Breeding Record of Turkey Vulture along South Saskatchewan River
}

\author{
by Dave Santy, Beechy
}

In mid-September, 1961, Mr. Gordon Prior caught a young Turkey Vulture (Cathartes aura) in the South Saskatchewan River hills near his farm in the Demaine district. The bird had a broken wing tip. By the efforts it made to escape at the time of its capture, Gordon believes the bird could have taken flight but for the broken wing. The appearance of the wound suggested that the accident had happened some time before, possibly when the bird was still a fledgling. After capturing it, Gordon provided food for it for over two weeks-its daily diet was a jack rabbit weighing more than the bird itself.

Showing fear at first, the vulture soon became used to people and even demanded attention. In the end it was taken to the Moose Jaw Wild Animal Park.

The head of the young vulture had not yet turned red. It had a sparse growth of black hair which Gordon described as a "crew cut"!

We have seen vultures in this territory at intervals dating back to the early 1920's. As they were usually in pairs we formed the belief that they nested here, but this find of a young bird is the first tangible evidence to support the belief.

Editor's Note: Among the birds sighted by Ralph Carson on a 10-day expedition into the South Saskatchewan River area this past summer for the Saskatchewan Museum of Natural History was an adult Turkey Vulture observed June 15, 1961, at Swift Current Creek.

\section{Unusual Nesting Sites of Brown Thrasher and Yellow-Shafted Flicker}

\section{by P. Laurence Beckie, Bladworth}

On June 11, 1961, I photographed a Brown Thrasher (Toxostoma rufum) at its nest in an unusual location. I had found the nest several days before when I took some empty cans to a stone pile. As the cans fell with a rattle a Brown Thrasher flew out from somewhere in the garbage heap. I soon found a nest with eggs built on a branch of a fallen dead tree. The dead branch protruded into an old round wash tub standing on its side, so the nest was sheltered in a quite unusual way. I visited the nest a few days after and found the Brown Thrasher sitting tight in defiance of my close approach. On my next visit in late July, the nest was naturally deserted; but I trust that the young were safely raised in this unusual nest site. For notes on a somewhat similar nest-site of this species see Blue Jay, $15: 103$.

In 1944 I had a Brown Thrasher nest in a box in some poplars. The nesting box was a crude one, placed in a tree about 12 feet above the ground. Bent (1948. Life Histories ...Thrashers...) cites two records of the Curve-billed Thrasher (Toxostoma.curvirostre) nesting in old woodpecker holes in trees, but the habit is certainly rare in this group. Apparently neither the Curve-billed Thrasher nor the Brown Thrasher has been recorded nesting in nestboxes and such a site must be unusual.

-Another oddity I found last summer (1961) was a family of Yellowshafted Flickers (Colaptes auratus) nesting in a telephone pole below ground level. The dwelling had been chipped out years ago by, predecessors of the 1961 tenants. Then the pole had rotted off and was reset with the entrance to the hole now being only six inches above the ground level. The inside cavity was about one foot deep, so the young were actually raised below ground! The elusiveness of the parents was unbelievable. I drove past the post nearly once a day during their occupancy and I didn't know it was in use until my brother Sam heard the buzzing of the young as he passed on his way to school.

(Continued on page 33 ) 